\title{
Pendampingan Pembelajaran Bahasa Inggris Siswa Sekolah Dasar di Masa Pandemi
}

\author{
Komang Dian Puspita Candra ${ }^{1}$, Putu Devi Maharani ${ }^{2}$, \\ Putu Subakthiasih ${ }^{3}$, I Made Agus Leo Miarta ${ }^{4}$
}

1, 2,3,4, Universitas Mahasaraswati Denpasar

'dianpuspitacandra@unmas.ac.id; ${ }^{2}$ devi.maharani@unmas.ac.id; ${ }^{3}$ subakthiasih@unmas.ac.id; 4 leomiarta889@gmail.com

\begin{abstract}
Abstrak
Pandemi Covid-19 memberikan dampak yang sangat serius untuk semua sektor kehidupan, salah satunya adalah sektor pendidikan. Pandemi ini menyebabkan sektor pendidikan harus beradaptasi dengan situasi pembelajaran daring tanpa persiapan yang matang sebagai salah satu upaya memutus penyebaran virus ini. Tujuan dari pelaksanaan pengabdian masyarakat dengan menyasar sekolah dasar karena penerapan sistem pembelajaran daring untuk kelas kecil yang berada dalam ruang lingkup sekolah dasar bukanlah hal yang mudah, sehingga pelaksanaannya harus dievaluasi sedini mungkin. Bentuk kegiatan pengabdian yang dapat dilakukan di sekolah dasar adalah berupa pendampingan yaitu pendampingan sebagai fasilitator dan juga pendampingan sebagai ruang belajar dengan waktu belajar yang flexible. Setelah dilakukan pendampingan pada pembelajaran Bahasa Inggris siswa kelas IV SDN 11 Dauh Puri Denpasaryang berjumlah 38 orang selama satu semester ditemukan perubahan sikap dari siswa. Motivasi siswa untuk belajar meningkat yang ditunjukkan dengan peningkatan hasil penilaian belajar siswa baik secara tertulis maupun lisan. Selain itu keaktifan siswa untuk berinteraksi menggunakan platform digital juga meningkat setiap bulannya yang menandakan siswa merasa nyaman menggunakan platform digital grup Whatsapp untuk berdikusi dan cloud zoom meeting untuk menunjang proses pembelajaran bahasa Inggris secara daring.
\end{abstract}

Kata Kunci: pendampingan, fasilitator, ruang belajar, platform digital

\section{Pendahuluan}

Pandemi Covid-19 memberikan dampak yang sangat serius untuk semua sektor kehidupan, salah satunya adalah sektor pendidikan. Dampak dari pandemi covid-19 ini akan mempengaruhi sektor pendidikan dalam jangka waktu yang panjang dan jangka waktu pendek (Aji, 2020). Di Indonesia, sektor pendidikan khususnya sekolah sangat mempengaruhi produktivitas dan pertumbuhan ekonomi (Baharin, 2020). Dengan demikian pelaksanaan pendidikan selama masa pandemi harus tetap terkontrol agar tidak mempengaruhi pertumbuhan ekonomi di Indonesia. Hal inilah yang melatarbelakangi kegiatan pengabdian masyarakat perlu menyasar bidang pendidikan khususnya pendidikan di Sekolah Dasar. Melalui kegiatan pengabdian masyarakat ini ingin dilakukan pendampingan ke sekolah dasar guna memantau dan menjaga kualitas proses pembelajaran yang dilakukan secara daring agar dapat berjalan dengan maksimal. Krisis kesehatan global yang diakibatkan oleh Coronavirus 2019 (COVID-19) telah 
menyerang Dunia hampir selama 1,5 tahun yang menyebabkan sektor pendidikan harus beradaptasi dengan situasi yang baru tanpa persiapan yang matang untuk melaksanakan pendidikan secara daring. Melakukan proses pembelajaran daring untuk kelas kecil yang berada dalam ruang lingkup sekolah dasar bukanlah hal yang mudah, sehingga pelaksanaannya harus dievaluasi sedini mungkin.

Mata pelajaran yang diajarkan di tingkat sekolah dasar beserta model pembelajaran yang dilakukan secara daring sangat berpengaruh bagi peningkatan kompetensi siswa. Penerapan model pembelajaran abad 21 yang diimplementasikan sejak SD dapat membuat siswa mengetahui bahwa pendidikan yang mereka tempuh sangat penting serta bermanfaat dalam menyelesaikan masalah dan situasi di dunia nyata sekarang ini (Afni, 2021). Diantara semua mata pelajaran di tingkat sekolah dasar, proses pembelajaran bahasa Inggris di sekolah dasar selama masa pandemi ini cukup mengkhawatirkan pasalnya bahasa Inggris tidak lagi menjadi mata pelajaran wajib dal am kurikulum 2013. Perubahan kurikulum ini merupakan salah satu upaya Pemerintah untuk memprioritaskan bahasa Indonesia dan bahasa daerah sebagai bahasa ibu. Dampak dari perubahan ini membuat beberapa Sekolah Dasar negeri di Bali memasukan pelajaran bahasa Inggris menjadi muatan lokal dengan porsi yang tidak terlalu banyak. Sedangkan pada Sekolah Dasar Swasta, pelajaran bahasa asing khususnya bahasa Inggris masih ditonjolkan sebagai nilai plus yang dimiliki sekolah tersebut.

Kendala-kendala yang ditemukan dalam mengajar bahasa Inggris kelas kecil secara daring di sekolah dasar adalah perlunya pendampingan yang maksimal selama siswa melakukan proses pembelajaran dari rumah masing-masing. Kondisi tersebut layak menjadi perhatian karena dalam situasi seperti ini disaat yang bersamaan orag tua sulit untuk mendampingi karena para orangtua juga harus bekerja. Kondisi lainnya, orangtua kurang memiliki pengetahuan untuk menggunakan teknologi yang dapat mendukung proses pembelajaran sebagai aplikasi dari model pembelajaran abad 21. Kond isi lainnya yang ikut menjadi kendala adalah fasilitas yang kurang memadai dalam melakukan pembelajaran secara daring, minimal perangkat seperti handphone atau laptop beserta jaringan internet harus disediakan oleh para orangtua siswa guna menunjang kelancaran proses pembelajaran.

Dapat dikatakan proses pembelajaran bahasa Inggris secara daring yang dilakukan di SDN11 Dauh Puri Denpasar, salah satu sekolah negeri yang ada di Denpasar belum berjalan dengan optimal karena kendala dari pihak siswa dan juga sekolah. Hal inilah yang tampak dari pengamatan yang telah dilakukan di SDN11 Dauh Puri Denpasar. Meskipun lokasi sekolah negeri ini berada di pusat kota yang strategis, namun para peserta didik di sekolah ini berasal dari keluarga menengah kebawah. Dalam situasi pandemi Covid 19 ini, sangat sulit rasanya bagi para orangtua untuk menyediakan fasilitas belajar daring yang dimiliki oleh anak secara pribadi. Sehinggajalan tengah yang disepakati pihak sekolah dan orangtua siswa adalah adanya keflexibelan bagi siswa untuk mengikuti pembelajaran secara daring dengan menggunakan handphone orangtua di sore hari setelah orangtua pulang bekerja. Pembelajaran yang dimaksud berupa waktu untuk pengumpulan tugas, maupun pencatatan materi yang diberikan di jam sekolah dapat dikerjakan oleh siswa maksimal dihari tersebut pada pukul 6 sore dan ada juga pekerjaan yang dikumpulkan langsung oleh orangtua ke sekolah. Namun, peluang ini tetap tidak dapat dilakukan secara maksimal oleh orangtua siswa sebagai 
pendamping dan juga Guru. Guru Bahasa Inggris di Sekolah tersebut hanya 1 dan terdapat 6 kelas yang berada dibawah pengawasannya, sehingga tidak terjadi umpan balik yang maksimal antara guru dan siswa apabila pengumpulan tugas maupun diskusi dilakukan diluar jam sekolah. Hal ini menyebabkan kurangnya pemahaman terhadap materi yang diberikan dan minat belajar siswamenurun.

Program pengabdian kepada masyarakat dalam bentuk asistensi atau pendampingan adalah solusi terbaik yang bisa ditawarkan untuk memperlancar proses pembelajaran bahasa Inggris secara daring di SDN 11 Dauh Puri Denpasar. Materi yang dirancang oleh guru bahasa Inggris di SD tersebut sudah baik untuk pandemi ini, namun dalam proses pelaksanaanya yang mengalami kendala. Kendala ini apabila tidak segera ditangani akan menimbulkan efek yang semakin memburuk pada siswa. Selain turunnya minat belajar, juga akan menimbulkan kejenuhan sebagai akibat kurangnya aktivitas yang dapat memotivasi siswa selama belajar secara daring dirumah. Berdasarkan permasalahanpermasalahan tersebut tim pelaksana pengabdian atas persetujuan Kepala Sekolah SDN11 Dauh Puri Denpasar sebagai mitra, melaksanakan kegiatan pengabdian pada masyarakat untuk anak-anak kelas IV di SDN 11 Dauh Puri Denpasar agar motivasi siswa untuk belajar bahasa Inggris kembali normal selama proses pembelajaran daring dari rumah masing-masing di masa pandemi ini sekaligus melalui kegiatan ini ingin membuat siswa melek terhadap penggunaan platform digital dalam aplikasi model pembelajaran di abad 21.

\section{Metode Pelaksanaan}

Kegiatan pengabdian masyarakat ini dilaksanakan selama satu semester yang dimulai pada bulan Januari s/d Juni 2021 bertempat di SDN 11 Dauh Puri yang beralamat di Jalan Pulau Batam No 28, Denpasar Bali. Lokasi pengabdian berjarak sekitar 3,3 kilometer dari Kampus Pusat Universitas Mahasaraswati Denpasar. Sekolah ini memiliki fasilitas yang lengkap seperti ruang kelas yang nyaman, perpustakaan, lapangan olahraga dan kantin. Sekolah ini juga memiliki reputasi yang baik dan lokasinya sangat strategis karena berada di pusat kota seperti yang dapat dilihat pada gamb ar dibawah ini.

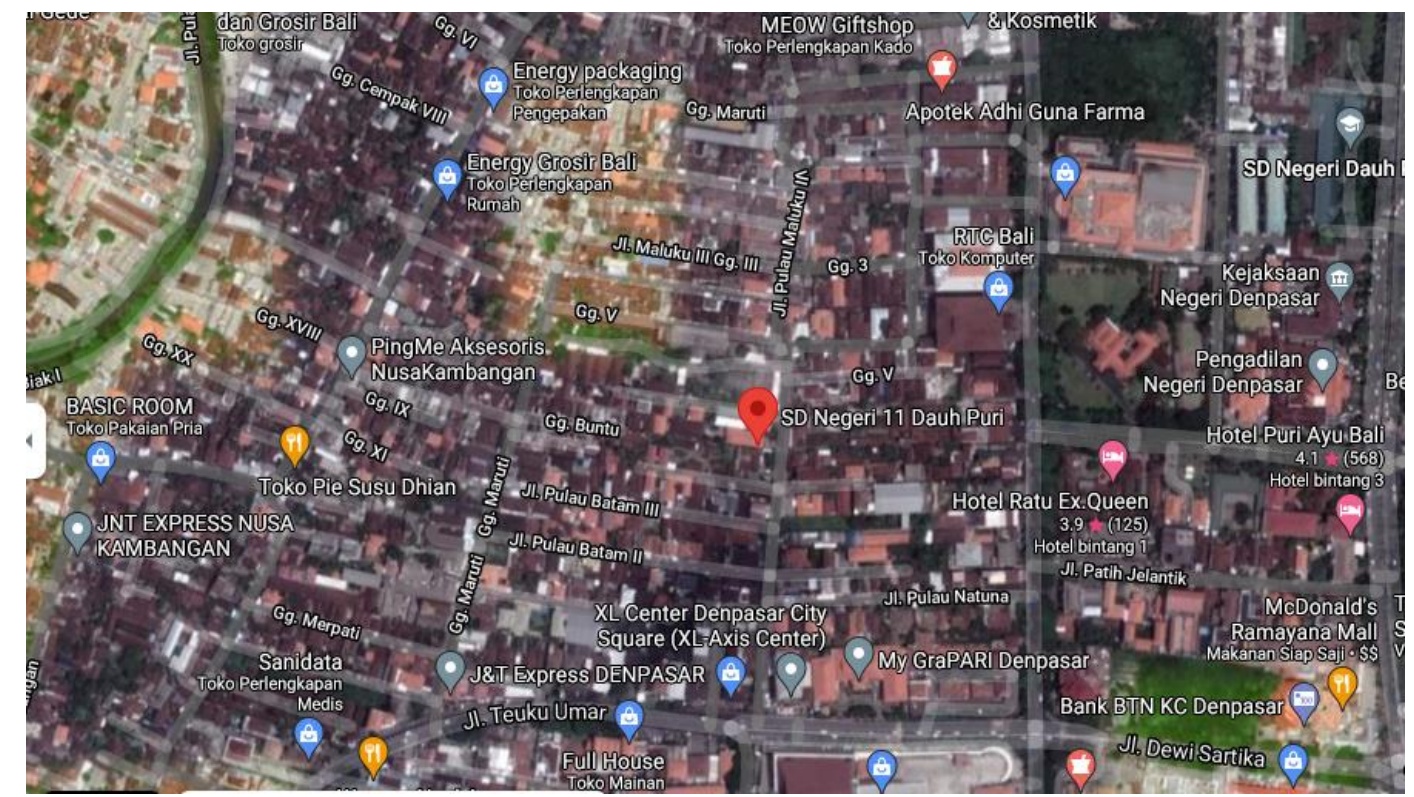

Gambar1. Peta Lokasi Pengabdian Masyarakat 
Sebelum melaksanakan pengabdian, tim pelaksana melakukan pengamatan dan wawancara terhadap pihak sekolah khusus untuk sekolah-sekolah negeri yang berada di seputaran Kota Denpasar. Berdasarkan hasil observasi dan wawancara tersebut diketahui beragam kendala yang dihadapi sekolah terkait proses pembelajaran daring. SDN 11 Dauh puri ini dipilih sebagai lokasi kegiatan pengabdian karenaberdasarkan hasil pengamatan program kerja yang disiapkan oleh tim pelaksana dirasa dapat membantu kendala yang dihadapi di sekolah tersebut diantaranya (1) sekolah ini hanya memiliki satu guru bahasa Inggris dengan status honorer yang diperbantukan di sekolah ini untuk mengajar bahasa Inggris di enam kelas yang berbeda. Hal ini menyebabkan timbulnya kendala dalam mengetahui perkembangan masing-masing siswa yang ada di SD tersebut selama proses pembelajaran dilakukan secara daring. (2) Berdasarkan hasil evaluasi terhadap siswa dalam mengikuti proses pembelajaran daring pada semester sebelumnya, diperoleh hasil bahwa minat belajar siswa menurun. Siswa kelas IV dipusatkan untuk menerima program pendampingan oleh tim pelaksana pengabdian karena secara psikologis siswa diumur ini sudah memiliki keberanian untuk berinteraksi dengan orang lain tanpa didampingi orangtua.

Kegiatan pengabdian masyarakat ini dilakukan dalam tiga tahapan yaitu (1) Tahapan prakegiatan, (2) Tahapan pelaksanaan kegiatan dan (3) Tahapan pasca kegiatan. Tahapan prakegiatan terbagi atas dua kegiatan penting yaitu observasi (pengamatan) dan wawancara. Kedua kegiatan ini sangat diperlukan guna mengetahui kebutuhan dari sekolah yang menjadi mitra untuk pelaksanaan pengabdian masyarakat. Tahapan Pelaksanaan Kegiatan dibedakan menjadi:

\section{(a) Pendampingan Sebagai Fasilitator}

Pendampingan dalam kegiatan ini adalah tim pelaksana pengabdian turut serta menjadi tim pengajar di kelas. Tim pelaksana mengambil alih tugas mengajar di kelas selama beberapakali pertemuan dengan melanjutkan materi sesuai yang diberikan oleh guru di sekolah. Sebelum melakukan tahapan ini, dilakukan kegiatan persamaan persepsi antara guru bahasa Inggris dan tim pelaksanan pengabdian guna memiliki konsep yang sama tentang materi yang akan diajarkan. Selain itu juga dilakukan pengayaan materi, dan persiapan powerpoint terkait materi yang diajarkan. Evaluasi dilakukan setiap akhir proses pembelajaran untuk mengetahui keberhasilan dari program pendampingan.

\section{(b) Pendampingan Dengan Membuka Ruang Belajar}

Pendampingan dengan membuka ruang belajar yang dimaksudkan adalah tim pelaksana pengabdian menyiapkan suatu platform digital yang digunakan sebagai tempat konsultasi para siswa yang memiliki kendala dalam memahami materi bahasa Inggris yang diajarkan. Ruang belajar dilakukan melalui grup Whatsapp, di mana kendala yang dialami mitra pada saat pembelajaran dan pemahaman materi dikonsultasikan terlebih dahulu di Whatsapp Group. Pelaksanaan pendampingan ini dimaksudkan untuk membantu menyelesaikan kendala yang dihadapi siswa. Kegiatan diskusi ini tidak mengenal waktu, kapan saja apabila ada yang ingin didiskusikan siswa dapat memanfaatkan grup Whatsapp tersebut. 
Tahapan yang terakhir adalah tahapan Evaluasi kegiatan. Dalam evaluasi tidak hanya dilakukan penilaian terhadap kemampuan siswa namun evaluasi juga dilakukan dengan cara penyebaran kuesioner terkait proses pendampingan yang dilakukan. Refleksi juga dilakukan oleh tim pelaksana pengabdian guna menilai sistem pembelajaran yang sudah diterapkan sehingga dapat dijadikan masukan untuk merancang kegiatan pendampingan yang maksimal padahari-hari berikutnya.

Indikator ketercapaian dari pelaksanaan kegiatan pendampingan ini adalah:

1. Meningkatnya minat belajar siswa dalam belajar bahasa Inggris secara daring ditunjukkan dengan peningkatan kemampuan siswa selama dilakukan kegiatan pendampingan.

2. Siswa memiliki rasa percaya diri untuk berinteraksi dan membuka diskusi atas hal-hal yang tidak dipahami.

3. Siswa mampu menggunakan platform digital untuk menunjang proses pembelajaran.

\section{Hasil dan Pembahasan}

Pelaksanaan kegiatan pengabdian masyarakat ini sudah berjalan dengan lancar sesuai program yang direncanakan dan hasil yang dicapai sudah sesuai dengan indikator ketercapaian kegiatan. Adapun indikator yang sudah dicapai adalah: (1) meningkatkan motivasi belajar siswa yang ditunjukkan dengan peningkatan nilai yang diperoleh siswa. Dalam hal penilaian, siswajuga memiliki kemampuanyang seimbang antara kemampuan menulis dan kemampuan berbicara. (2) siswaberani berinteraksi melalui grup whatsapp untuk menanyakan hal-hal yang belum dipahami dan (3) siswa sudah bisa menggunakan platform digital cloud zoom meeting dan juga whatsapp untuk menunjang proses pembelajaran daring. Hal ini dapat terjadi karena kerjasama yang baik antar tim pelaksana pengabdian, pihak sekolah dan dukungan para orang tua siswa. Terdapat beberapa kendala diawal pendampingan namun dapat diatasi dengan komunikasi yang baik antar pihak. Indikator ketercapaian yang dimaksud dapat dilihat dari pelaksanaan dua program kerjaberikutini:

\section{Pendampingan sebagai Fasilitator}

Selama menjadi fasilitator (tim pengajar) diperoleh peningkatan hasil belajar siswa serta kemampuan tulis dan oral siswa seimbang. Adapun materi yang diajar dibedakan kedalam dua topik yaitu: (1) Bab 8 tentang ordinal number dan (2) Bab 9 tentang Season. Proses pembelajaran daring dilakukan melalui grup Whatsapp dan untuk tatap muka menggunakan cloud Zoom meeting. Foto dibawah merupakan contoh pemberian materi melalui grup Whatsapp dan juga menggunakan cloud zoom meeting. 


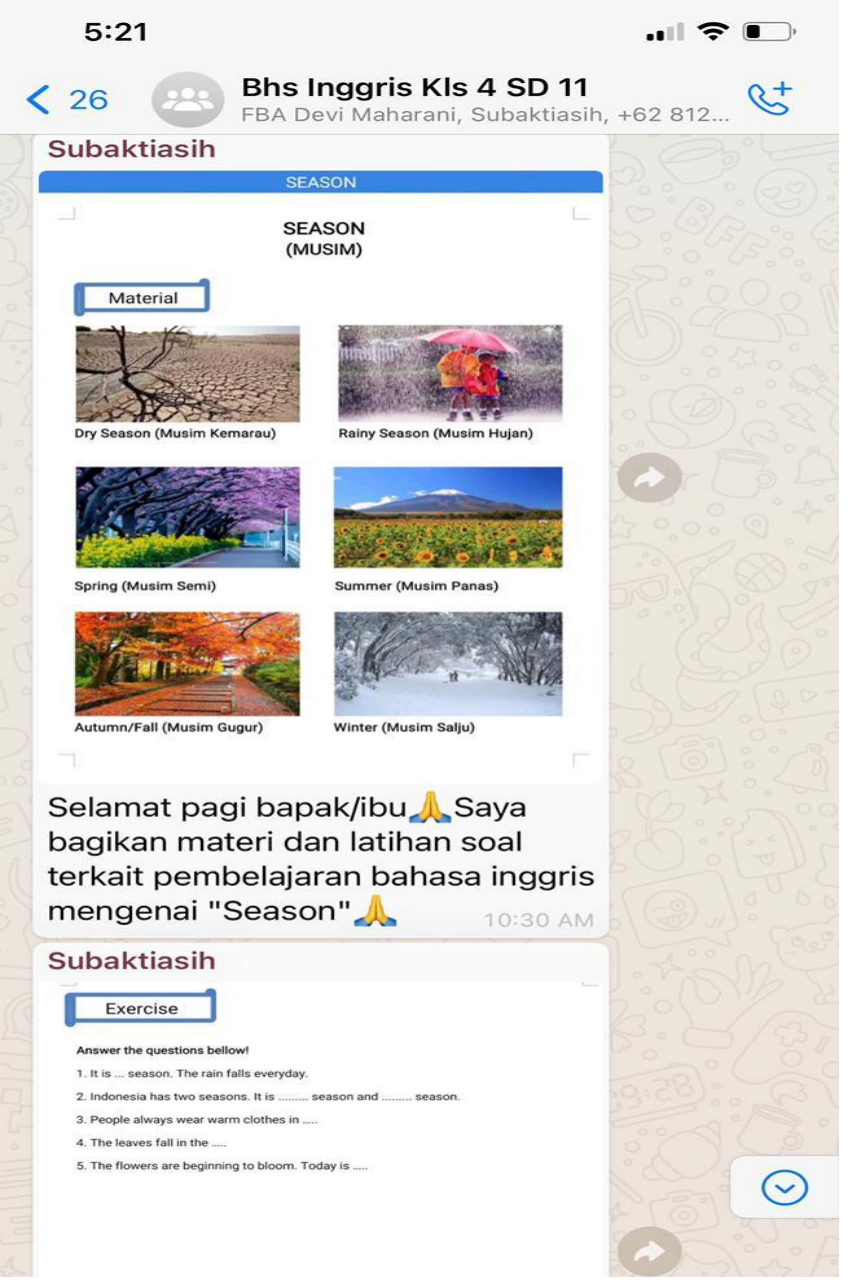

Gambar 2. Pemberian Materi Melalui Cloud Zoom Meeting

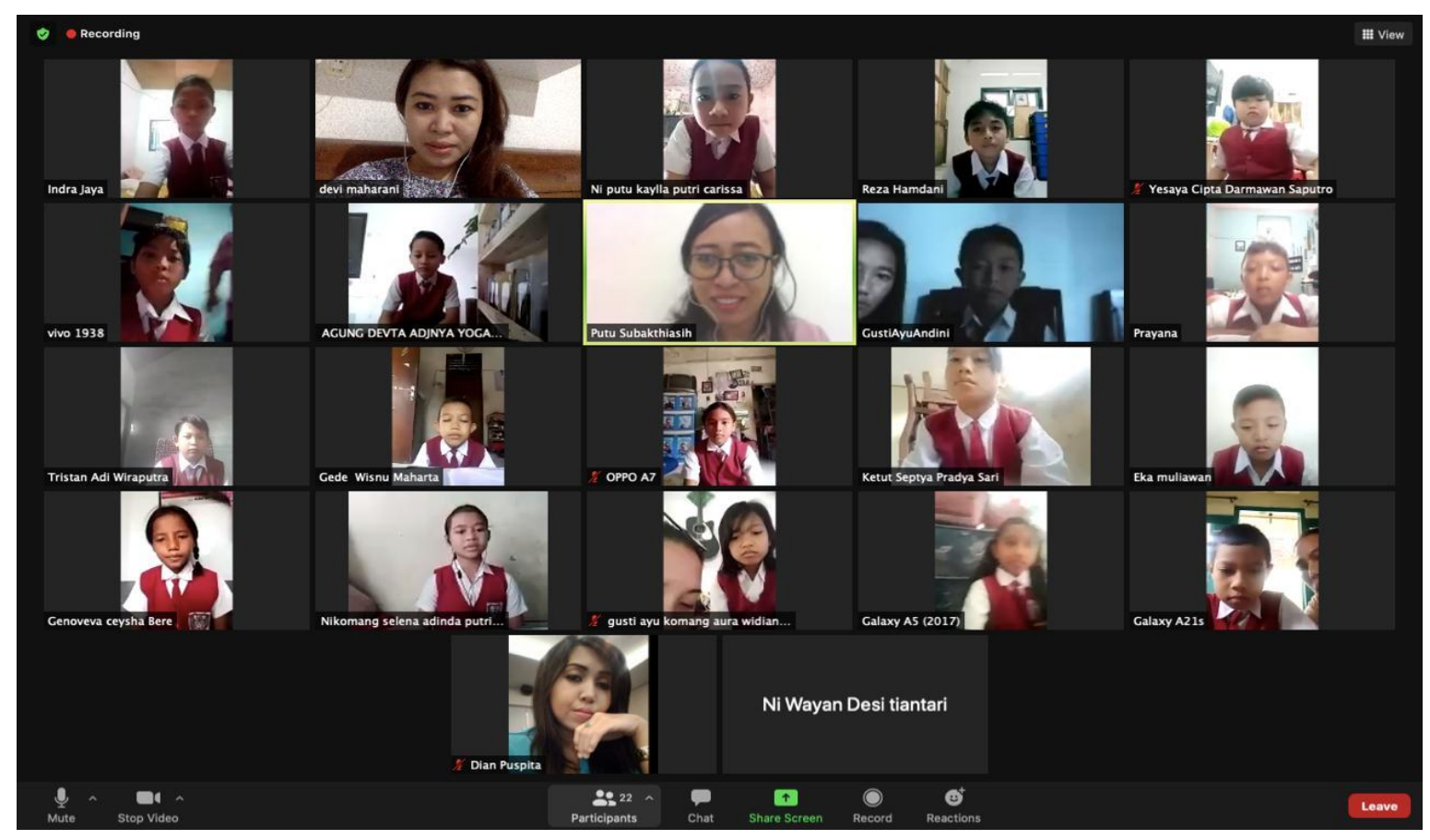

Gambar3. Pembelajaran Tatap Muka Menggunakan Cloud Zoom Meeting 
Vol. 2, No. 3, Agustus 2021

ISSN 2721-4834

Keberhasilan selama pendampingan ini dapat dilihat dari nilai siswa yang mengalami peningkatan selama proses pembelajaran dilakukan oleh tim pelaksana pengabdian. Penilaian dilakukan dalam dua versi yaitu dengan mengirimkan foto jawaban melalui group whatsapp dan pada saat kelas tatap muka melalui cloud zoom meeting dengan menjawab pertanyaan secara langsung. Hal ini dilakukan untuk meyakinkan proses pembelajaran memang benar-benar dilalui oleh siswa secara mandiri tanpa bantuan orangtua selama mengerjakan tes evaluasi. Berikut adalah contoh saat siswa menyetorkan pekerjaannya melalui grup whatsapp.

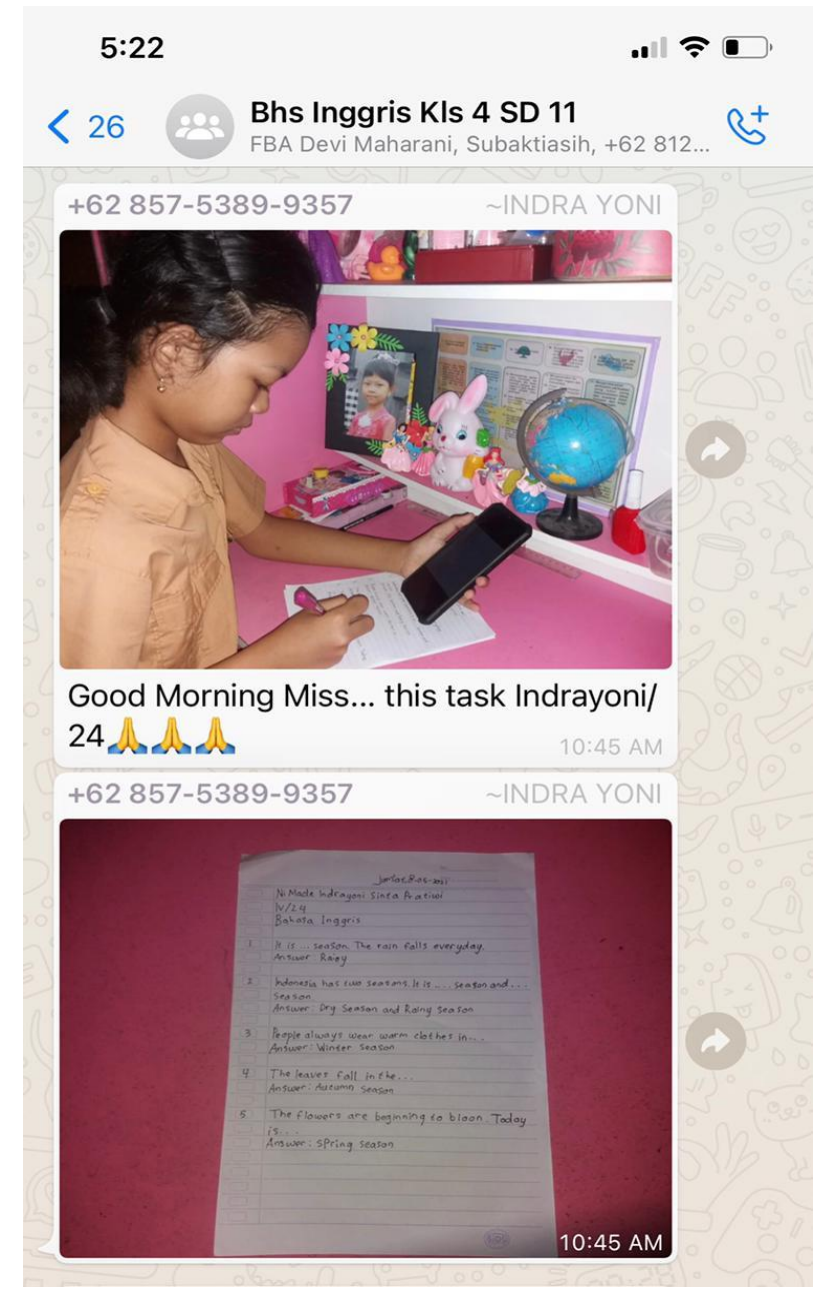

Gambar 4. Proses Pembelajaran Daring Melalui Grup Whatsapp

Nilai rata-rata siswa yang diperoleh dalam proses pembelajaran yang dilakukan oleh tim pelaksana pengabdian masyarakat tercantum pada Tabel 1.

Tabel 1. Nilai Rata-Rata Siswa Dalam Proses Pembelajaran Asistensi

\begin{tabular}{llllll}
\hline \multirow{2}{*}{ NO } & \multirow{2}{*}{ NAMA SISWA } & \multicolumn{3}{l}{ TOPIK 1 } & \multicolumn{2}{l}{ TOPIK 2 } \\
\cline { 3 - 6 } & & Tes & Tes & Tes & Tes \\
& & Tulis & Oral & Tulis & Oral \\
\hline 1 & Agung Devta Adjnya Yogangga & 75 & 70 & 75 & 75 \\
2 & Agung Dwipayana Rifki Putra Bramantha & 75 & 75 & 80 & 80 \\
3 & Agus Kadek Moriski Angelo & 80 & 80 & 80 & 82 \\
\hline
\end{tabular}




\begin{tabular}{|c|c|c|c|c|c|}
\hline \multirow[b]{2}{*}{ NO } & \multirow[b]{2}{*}{ NAMA SISWA } & \multicolumn{2}{|c|}{ TOPIK 1} & \multicolumn{2}{|c|}{ TOPIK 2} \\
\hline & & $\begin{array}{l}\text { Tes } \\
\text { Tulis }\end{array}$ & $\begin{array}{l}\text { Tes } \\
\text { Oral }\end{array}$ & $\begin{array}{l}\text { Tes } \\
\text { Tulis }\end{array}$ & $\begin{array}{l}\text { Tes } \\
\text { Oral }\end{array}$ \\
\hline 4 & Alfio Ananda Asyari & 80 & 80 & 80 & 82 \\
\hline 5 & Andreansyah & 80 & 80 & 80 & 85 \\
\hline 6 & Arie Fahrizal & 85 & 85 & 85 & 85 \\
\hline 7 & Aulia Cahya Melani & 80 & 85 & 85 & 88 \\
\hline 8 & Ayumi Purnama Putri & 80 & 82 & 85 & 85 \\
\hline 9 & Bagus Mulyono Putra & 80 & 85 & 85 & 85 \\
\hline 10 & EkaMuliawan & 80 & 80 & 80 & 80 \\
\hline 11 & Gede Wisnu Maharta & 90 & 90 & 90 & 92 \\
\hline 12 & Genoveva Ceysha Bere & 90 & 90 & 92 & 90 \\
\hline 13 & I Gede Purnama Putra & 90 & 90 & 90 & 90 \\
\hline 14 & I Gusti Ngurah Arya Raditya Pramana & 85 & 85 & 85 & 88 \\
\hline 15 & I Komang Wirya Guna & 90 & 90 & 90 & 92 \\
\hline 16 & Jessica Anggie Diartawan & 75 & 80 & 80 & 80 \\
\hline 17 & KayzaParamitha Nurajmi & 80 & 80 & 85 & 85 \\
\hline 18 & Ketut Septya Pradnya Sari & 80 & 80 & 80 & 82 \\
\hline 19 & Komang Mahesa Putra & 85 & 85 & 85 & 85 \\
\hline 20 & Komang Tristan Adi Wiraputra & 90 & 90 & 90 & 92 \\
\hline 21 & Meilanie Yahya & 90 & 90 & 90 & 90 \\
\hline 22 & Muhammad Reza Hamdani & 90 & 90 & 100 & 90 \\
\hline 23 & Ni Komang Selena Adinda Putri & 80 & 90 & 90 & 90 \\
\hline 24 & Ni Made Indrayoni Sinta Pratiwi & 80 & 80 & 85 & 85 \\
\hline 25 & Ni Putu Kaylla Putri Carissa & 80 & 80 & 85 & 85 \\
\hline 26 & Ni Putu Kinan Dyantari & 80 & 80 & 85 & 85 \\
\hline 27 & Ni Putu Widya Puspa Fitriani & 100 & 90 & 100 & 90 \\
\hline 28 & Ni Wayan Desi Tiantari & 90 & 90 & 90 & 90 \\
\hline 29 & Nuril Anwar & 90 & 90 & 90 & 92 \\
\hline 30 & OktaviaAyu Lestari & 100 & 90 & 100 & 90 \\
\hline 31 & Olivia Gresia Moru Manek & 90 & 85 & 90 & 85 \\
\hline 32 & Putu Krisna Tirta Chanda & 85 & 85 & 85 & 85 \\
\hline 33 & Putu Prayana Wibawa Putra & 100 & 90 & 100 & 92 \\
\hline 34 & Riski Cahyadi & 90 & 85 & 90 & 85 \\
\hline 35 & Sakila Intan Nur Cahyani & 80 & 80 & 80 & 80 \\
\hline 36 & Wahyu Sulastiyo & 80 & 82 & 85 & 85 \\
\hline 37 & Yesaya Cipta Darmawan Saputro & 80 & 85 & 85 & 85 \\
\hline 38 & I Gusti Ayu Komang Aurra Widiantari & 100 & 90 & 100 & 90 \\
\hline
\end{tabular}

\section{Pendampingan dengan Membuka Ruang Belajar}

Keaktifan siswa selama pendampingan tidak hanya terlihat dari peningkatan kemampuan siswa selama mengikuti pelajaran, namun juga terlihat dari pemanfaatan ruang belajar yang disiapkan melalui grup Whatsapp. Jumlah siswa yang bertanya menggunakan ruang belajar ini meningkat setiap bulannya yang menandakan siswa mulai percaya diri untuk berinteraksi menggunakan media digital. Siswa juga tidak malu 
Vol. 2, No. 3, Agustus 2021

ISSN 2721-4834

bertanya hal-hal yang tidak diketahui sebelumnya serta sharing tentang kendala dalam memahami materi pembelajaran daring. Berikut adalah grafik jumlah pertanyaan siswa yang memanfaatkan ruang konsultasi apabila dikalkulasi setiap bulannya.

\section{Frekuensi Pertanyaan Siswa pada Saat Penerapan Program Ruang Belajar}

Penilaian kebermanfaatan kegiatan pengabdian masyarakat ini juga dilakukan dengan menyebarkan kuesioner kepada siswa diakhir kegiatan. Kuesioner dibuat menggunakan kalimat yang sederhana agar siswa dapat memahami maksud pertanyaan dan menjawab sesuai kenyataan yang dirasakan. Berikut adalah feedback siswa terhadap kuesioner yang disebarkan.

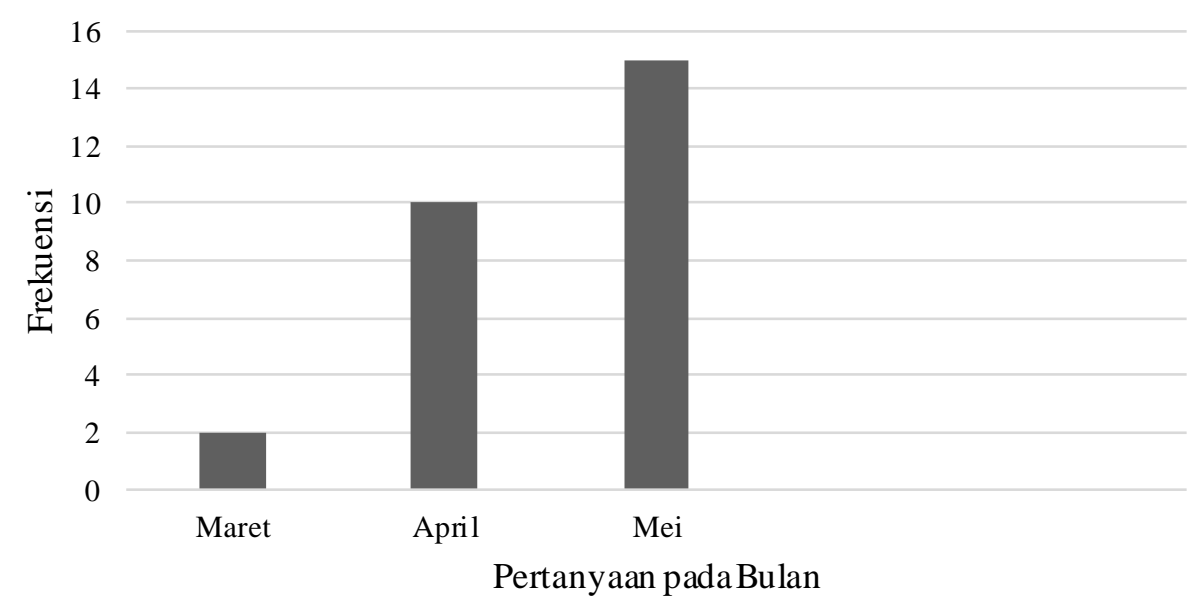

Gambar 5. Grafik Frekuensi Pertanyaan Siswa melalui Asistensi Ruang Konsultasi

Dari 38 orang siswa di kelas tersebut, hanya 30 orang yang mengisi kuesioner. Namun dengan jumlah tersebut sudah dapat mewakili pendapat dari kelas yang dilakukan pendampingan. Lima pertanyaan yang terdapat dalam kuesioner mendapat responyang positif dari siswa diantaranya, (1) siswa merasa terbantu dengan kegiatan pengabdian masyarakat ini, (2) siswa merasa lebih nyaman dan menyenangkan belajar dengan ssistem asistensi yang dilakukan oleh tim pengabdian, (3) orangtua siswa juga merasa terbantu dan nyaman dengan kegiatan pendampingan yang dilakukan, (4) siswa maupun orang tua siswa berharap kegiatan serupa dapat dilakukan kembali.

Tabel 2. Rangkuman Hasil Kuesioner Siswa

\begin{tabular}{llll}
\hline No & Pertanyaan & Ya & Tidak \\
\hline 1 & $\begin{array}{l}\text { Apakah anda merasa terbantu dengan kegiatan pendampingan } \\
\text { yang dilakukan? }\end{array}$ & 30 & 0 \\
2 & $\begin{array}{l}\text { Apakah pendampingan menggunakan Grup Whatsapp dan Cloud } \\
\text { Zoom meeting meningkatkan minat belajar }\end{array}$ & 25 & 5 \\
& $\begin{array}{l}\text { Apakah pendampingan dengan Grup Whatsapp dan Cloud Zoom } \\
\text { Meeting Lebih Menyenangkan daripada model belajar Daring yang } \\
\text { diterapkan Guru Sekolah? }\end{array}$ & 29 & 1 \\
3 & $(96,6 \%)$ & $(3,3 \%)$
\end{tabular}




\begin{tabular}{llll}
\hline No & Pertanyaan & Ya & Tidak \\
\hline 4 & $\begin{array}{l}\text { Apakah anda ingin mendapat pendampingan kembali dari tim } \\
\text { pelaksanaPengabdian? }\end{array}$ & 30 & 0 \\
& $\begin{array}{l}\text { Apakah Orang tua/Wali merasa terbantu dengan kegiatan } \\
\text { Pendampingan ini? }\end{array}$ & 30 & 0 \\
5 & (100\%) & (0\%) \\
\hline
\end{tabular}

\section{Kesimpulan}

Kegiatan pengabdian masyarakat ini dilakukan dengan tujuan memberikan pendampingan kepada sekolah agar dapat melaksanakan proses pembelajaran daring secara maksimal. Terdapat dua kegiatan yang diterapkan dalam pengabdian masyarakat ini yaitu (1) Pendampingan sebagai Fasilitator dan (2) Pendampingan sebagai Ruang Belajar. Kedua bentuk asistensi ini memberikan dampak yang positif untuk mengurangi kendala yang dihadapi siswa dalam mengikuti proses pembelajaran daring. Melalui kegiatan pendampingan sebagai fasilitator, dapat dilihat perkembangan siswa dalam memahami materi yang diberikan selama pendampingan. Nilai siswa sama baiknya dari hasil penugasan tertulis dan penugasan secara oral. Keaktifan siswa dalam memanfaatkan pendampingan sebagai ruang belajar digunakan siswa dengan baik terutama di Bulan Mei karena pada saat itu siswa mengikuti Penilaian Akhir semester di sekolah. Melalui kegiatan pendampingan ini siswa memiliki pengetahuan baru untuk menggunakan perangkat digital guna terlaksananya pembelajaran daring secara maksimal. Berdasarkan hasil kuesioner yang diberikan kepada siswa terkait kedua program pendampingan, siswa memberikan feedback yang positif dan merasa terb antu dengan kegiatan pengabdian masyarakat ini. Pendampingan yang dilakukan oleh tim pelaksana pengabdian ini diharapkan tetap dapat dilanjutkan oleh pihak sekolah sehingga dampak positif dari pembelajaran daring dapat dirasakan secara signifikan. Demikian pula untuk tim pelaksana pengabdian lainnya, model pendampingan yang telah diterapkan ini dapat dikombinasikan dengan model pembelajaran lainnya yang sesuai dengan model pembelajaran di Abad 21.

\section{Ucapan Terimakasih}

Pada kesempatan ini izinkan penulis menyampaikan terimakasih kepada seluruh pihak yang telah membantu pelaksanaan dari kegiatan pengabdian masyarakat ini diantaranya:

1. Rektor Universitas Mahasaraswati Denpasar, yang telah memberikan ijin untuk pelaksanaan kegiatan.

2. Dekan Fakultas Bahasa Asing, yang telah memberikan dukungan selama kegiatan Pengabdian masyarakat dilakukan.

3. Ketua LPPM Universitas Mahasaraswati Denpasar yang telah memberikan pengarahan dan motivasi selama pelaksanaan kegiatan.

4. Kepala Sekolah, Wali Kelas IV dan Guru Bahasa Inggris di SDN11 Dauh Puri yang telah memberikan kesediaannya untuk menjadi mitra dalam kegiatan pengabdian ini. 
Vol. 2, No. 3, Agustus 2021

ISSN 2721-4834

\section{Referensi}

Afni, N., Wahid, A., Hastati, S., Jumrah, A. M., \& Mursidin, M. (2021). Pengembangan Model Pembelajaran Abad 21 di SD Negeri 126 Borong Kecamatan Herlang Kabupaten Bulukumba. Madaniya,2(2), 137-142. https://doi.org/10.53696/27214834.66

Aji, R. (2020). Dampak Covid-19 pada Pendidikan di Indonesia:Sekolah, Keterampilan, dan Proses Pembelajaran. SALAM: Jurnal Sosial dan Budaya Syar-i, 7(5), 395-402. https://doi.org/10.15408/sjsbs.v7i5.15314

Baharin, R., Syah Aji, R., Yussof, I., Mohd Saukani, N. (2020). Impact of Human Resource Investment on Labor Productivity in Indonesia. Iranian Journal of Management Studies, 13(1), 139-164. https://doi.org/10.22059/ijms.2019.280284.673616

Bambang, L., Husain, S. N., \& Rede, A. (2015). Penerapan pembelajaran media audio visual untuk meningkatkan motivasi dan hasil belajar pada mata pelajaran biologi di kelas VIII A SMP GKST Imanuel Palu. Jurnal Sains dan Teknologi Tadulako, 4(1), 2328.

CNN Indonesia. (2020). Problematika anaksaat sekolah daring [Video]. YouTube. https://www.youtube.com/watch?v=5iEtW1qr2Ek\&list=WL\&index=22

Fauzyah, G. A. H., Maula, L. H., \& Nurasiah, I. (2021). Pengaruh pendampingan orang tua pada pembelajaran daring terhadap kecerdasan emosional. Jurnal Pendidikan Dasar, 11(2), 197-206. http://journal.unj.ac.id/unj/index.php/jpd/article/view/15872 